\title{
PENGARUH JENIS BAKTERI PELARUT FOSFAT (BPF) DAN JENIS PUPUK FOSFAT TERHADAP PERTUMBUHAN DAN PRODUKSI TANAMAN MENTIMUN (Cucumis sativus L.)
}

\section{THE EFFECT OF PHOSPHATE SOLUBILIZING BACTERIA (PSB) AND PHOSPHATE FERTILIZER ON THE GROWTH AND THE YIELD OF CUCUMBER (Cucumis sativus L.)}

\author{
Andi Setiadi ${ }^{1}$, Dermiyati ${ }^{2}$, Yohannes C. Ginting ${ }^{1}$, Kus Hendarto $^{1}$, Suskandini Ratih ${ }^{2}$ dan Mareli Telaumbanua ${ }^{3}$ \\ ${ }^{1}$ Jurusan Agroteknologi Fakultas Pertanian Universitas Lampung, Bandar Lampung, Indonesia \\ ${ }^{2}$ Jurusan Proteksi Tanaman Fakultas Pertanian Universitas Lampung, Bandar Lampung, Indonesia \\ ${ }^{2}$ Jurusan Teknologi Pertanian Fakultas Pertanian Universitas Lampung, Bandar Lampung, Indonesia \\ *Email: dermiyati.1963@fp.unila.ac.id \\ * Corresponding Author, Diterima: 15 Feb. 2021, Direvisi: 5 Apr. 2021, Disetujui: 24 Mei 2021
}

\begin{abstract}
The research aimed to determine the effect of phosphate solubilizing bacteria (PSB), phosphate fertilizer, and the interaction of both in increasing the growth and the yield of cucumber plants. This research was conducted at the intergrated field laboratory, Agriculture's Faculty, University of Lampung. This Research was designed using a completely randomized design (CRD) factorial consisting of 2 factors and each was repeated 3 times. The first factor was the type of phosphate fertilizer consisting of: control $\left(P_{\theta}\right)$, $S P-36150 \mathrm{~kg} \mathrm{ha}^{-1}\left(P_{1}\right)$ and phosphate rock 192,85 $\mathrm{kg} \mathrm{ha}^{-1}\left(P_{2}\right)$. The second factor was the type of PSB consisting of: control (M), PSB from extract suspension of oil palm bunches $\left(M_{1}\right)$, PSB from extract suspension of pineapple rhizome $\left(M_{2}\right)$, and PSB from extract suspension of oil palm bunches and pineapple rhizome $\left(M_{3}\right)$. The results showed that phosphate solubilizing bacteria (PSB) has no effect on the growth and the yield of cucumbers. SP-36 fertilizer increased the production and number of fruit compared with no $P$ fertilizer followed by an increase in the variable root dry weight, stover dry weight, flowering age, and number of female flowers. PSB from extract suspension of oil palm bunches with SP36 increased the growth of cucumber plants based on plant length and number of leaves.
\end{abstract}

Keywords: Cucumber, phosphate fertilizer, phosphate solubilizing bacteria.

\begin{abstract}
ABSTRAK
Penelitian ini bertujuan untuk mengetahui pengaruh bakteri pelarut fosfat (BPF), pupuk fosfat, dan interaksi keduanya dalam meningkatkan pertumbuhan dan produksi tanaman mentimun. Penelitian dilakukan di Laboratorium Lapang Terpadu Fakultas Pertanian Universitas Lampung. Penelitian ini menggunakan rancangan acak lengkap (RAL) faktorial yang terdiri dari 2 faktor dan masing-masing diulang sebanyak 3 kali. Faktor pertama merupakan jenis pupuk fosfat yang terdiri dari: tanpa pupuk fosfor $\left(\mathrm{P}_{0}\right)$, SP-36 $150 \mathrm{~kg} \mathrm{ha}^{-1}\left(\mathrm{P}_{1}\right)$ dan BFA 192,85 kg ha-1 $\left(\mathrm{P}_{2}\right)$. Faktor kedua merupakan jenis BPF yang terdiri dari: tanpa BPF $\left(\mathrm{M}_{0}\right)$, BPF dari suspensi MOL TKKS $\left(\mathrm{M}_{1}\right)$, BPF dari suspensi MOL rimpang nanas $\left(\mathrm{M}_{2}\right)$, dan kombinasi BPF dari suspensi MOL TKKS dan rimpang nanas $\left(\mathrm{M}_{3}\right)$. Hasil penelitian menunjukkan bahwa bakteri pelarut fosfat (BPF) tidak berpengaruh terhadap
\end{abstract}


pertumbuhan dan produksi tanaman mentimun. Pupuk SP-36 menghasilkan produksi dan jumlah buah mentimun lebih baik dibandingkan dengan tanpa pupuk $\mathrm{P}$ yang didukung oleh peningkatan variabel bobot kering akar, bobot kering brangkasan, usia berbunga, jumlah bunga betina. BPF dari MOL TKKS dengan pupuk SP-36 memberikan pengaruh lebih baik terhadap panjang tanaman dan jumlah daun.

Kata kunci : Bakteri pelarut fosfat, mentimun, pupuk fosfat.

\section{PENDAHULUAN}

Mentimun (Cucumis sativus L.) merupakan tanaman sayur buah yang banyak diminati di Indonesia. Mentimun memiliki kandungan nutrisi yang baik dan rasanya yang segar sebagai pelengkap berbagai jenis kuliner yang ada di Indonesia. Produksi mentimun di Indonesia pada tahun 2017 adalah sebanyak 433.965 ton dengan luasan panen sebesar 39.850 ha (BPS, 2018). Sehingga, produktivitas mentimun pada tahun 2017 sebanyak 10,89 ton ha ${ }^{-1}$. Produktivitas tersebut baru mencapai $21,78 \%$ dari produktivitas potensial yang dapat dihasilkan oleh tanaman mentimun, yaitu sebesar 50 ton $\mathrm{ha}^{-1}$.

Upaya yang dapat dilakukan untuk meningkatkan produktivitas mentimun yakni dengan memberikan unsur hara yang cukup agar tanaman dapat tumbuh dan berproduksi secara optimal. Salah satu kendala kesuburan tanah di Provinsi Lampung adalah rendahnya ketersediaan unsur $\mathrm{P}$ dalam tanah. Hal tersebut disebabkan oleh jenis tanah di Lampung yang umumnya berjenis Ultisol. Tanah Ultisol merupakan jenis tanah dengan sifat asam yang mengandung banyak ion-ion $\mathrm{Al}$ dan Fe di dalam tanah. Adanya ion-ion asam tersebut mengakibatkan unsur $\mathrm{P}$ yang ditambahkan ke dalam tanah akan terikat menjadi Al-P, Fe-P, dan Occluded-P sehingga unsur P tersebut tidak tersedia untuk dimanfaatkan oleh tanaman.
Salah satu upaya untuk meningkatkan efisiensi pemupukan fosfat dalam mengatasi ketersediaan fosfat tersedia di dalam tanah dengan memanfaatkan kelompok Bakteri Pelarut Fosfat (BPF). BPF adalah bakteri yang dapat melarutkan fosfat yang terikat menjadi fosfat yang tersedia untuk tanaman. Bakteri pelarut fosfat mempunyai kemampuan melarutkan fosfat-anorganik tak larut dengan mensekresikan asamasam organik sehingga melepaskan fosfat yang terikat di dalam koloid tanah (Subba-Rao, 1982). Sumber pengambilan BPF dapat diperoleh dari beberapa sumber bahan organik seperti limbah tandan kosong kelapa sawit (TKKS) dan juga rimpang nanas (RN). TKKS dan RN merupakan limbah pabrik yang memiliki potensi untuk menghasilkan BPF yang mampu melarutkan $\mathrm{P}$ terikat di dalam tanah dengan baik. Berdasarkan hasil penelitian sebelumnya, telah diperoleh 7 jenis isolat BPF dari suspensi MOL TKKS dan 4 jenis isolat BPF dari suspensi MOL RN yang memiliki kemampuan melarutkan P yang terikat di tanah dengan sangat tinggi (Dermiyati et al., 2019).

Penambahan unsur $\mathrm{P}$ ke dalam tanah banyak dilakukan dengan penambahan pupuk $\mathrm{P}$ anorganik. Selain pupuk kimia P seperti SP-36, juga terdapat jenis pupuk P potensial yang berupa Batuan Fosfat Alam (BFA). BFA merupakan batuan fosfat yang telah dihaluskan dan memiliki kandungan P dengan standar 
yang telah ditentukan. Sayangnya, BFA masih memiliki kelemahan berupa tingkat kelarutan yang rendah bila dibandingkan dengan pupuk kimia seperti SP-36. Sehingga, diperlukan suatu usaha yang dapat meningkatkan kelarutannya seperti penggunaan bakteri pelarut fosfat (BPF).

Tujuan dari penelitian ini adalah untuk mengetahui pengaruh dari jenis $\mathrm{BPF}$, jenis pupuk fosfat, dan interaksi keduanya dalam meningkatkan pertumbuhan dan produksi tanaman mentimun.

\section{BAHAN DAN METODE}

Penelitian dilakukan di Laboratorium Lapang Terpadu Fakultas Pertanian Universitas Lampung pada bulan Juni sampai Oktober 2019. Perbanyakan BPF dan pembuatan konsorsium BPF dilakukan di Laboratorium Bioteknologi Pertanian Universitas Lampung.

Penelitian ini menggunakan rancangan faktorial 3 x 4 dalam Rancangan Acak Lengkap (RAL), setiap perlakuan diulang sebanyak 3 kali. Faktor pertama merupakan jenis sumber pupuk fosfat yang terdiri dari: tanpa pupuk $\mathrm{P}\left(\mathrm{P}_{0}\right), \mathrm{SP}-36150 \mathrm{~kg} \mathrm{ha}^{-1}\left(\mathrm{P}_{1}\right)$ dan BFA $192,85 \mathrm{~kg} \mathrm{ha}^{-1}\left(\mathrm{P}_{2}\right)$. Faktor kedua merupakan jenis BPF yang terdiri dari: tanpa BPF $\left(\mathrm{M}_{0}\right)$, BPF dari MOL TKKS $\left(\mathrm{M}_{1}\right)$, BPF dari MOL RN $\left(\mathrm{M}_{2}\right)$, dan kombinasi BPF dari MOL TKKS+RN $\left(\mathrm{M}_{3}\right)$.

Data hasil pengamatan diuji kehomogenannya dengan Uji Bartlett dan uji aditivitas data dengan menggunakan Uji Tukey. Bila kedua asumsi terpenuhi, data dianalisis dengan dengan analisis ragam (ANARA) dan dilanjutkan dengan ujilanjut menggunakan Uji DMRT (Duncan's Multiple Range Test) pada taraf 5\%.
Peremajaan BPF dilakukan di dalam tabung reaksi dengan menggunakan media potato pepton glucose agar (PPGA). Peremajaan BPF dilakukan dalam kondisi aseptik di dalam Laminar Air Flow (LAF). Setiap isolat BPF diambil menggunakan jarum ose sebanyak 1 ose, kemudian digoreskan pada media agar miring PPGA yang telah disediakan. Media tanam yang digunakan yaitu tanah permukaan (top soil) pada kedalaman $0-20 \mathrm{~cm}$ yang diperoleh dari tanah Laboratorium Lapang Terpadu Fakultas Pertanian Unila dengan jenis tanah Ultisol. Tanah selanjutnya dijemur selama $3-5$ hari hingga tanah kering. Selanjutnya tanah diayak dengan lebar ayakan $5 \mathrm{~mm}$ kemudian dimasukkan ke dalam polybag ukuran 50 x $50 \mathrm{~cm}$ dengan bobot tanah masing-masing seberat $10 \mathrm{~kg}$. Hasil analisis sampel tanah awal ditunjukkan pada Tabel 1.

Penanaman benih ke dalam polybag dilakukan pada sore hari dengan kedalaman $5 \mathrm{~cm}$ dengan jumlah benih per polybag sebanyak 2 butir benih mentimun. Jarak tanam disusun dengan jarak antar baris selebar $80 \mathrm{~cm}$ dan jarak dalam barisan selebar $60 \mathrm{~cm}$ serta jarak antar bedengan selebar $50 \mathrm{~cm}$. Penyulaman tanaman dilakukan saat tanaman berumur 5 HST untuk mengganti tanaman yang tidak tumbuh serta dilakukan seleksi tanaman pada bibit yang pertumbuhannya kurang baik lalu disisakan satu tanaman per lubang tanaman.

Pupuk dasar yang digunakan berupa Urea dan $\mathrm{KCl}$ yang diberikan sesuai dosis rekomendasi untuk tanaman mentimun. Sedangkan pupuk P diberikan sesuai dengan perlakuan yang terdiri SP-36 dan BFA Maroko. Pupuk Urea diberikan dengan dosis $225 \mathrm{~kg}$ ha $^{-1}\left(1,125 \mathrm{~g}\right.$ tanaman $\left.^{-1}\right)$ untuk diaplikasikan 
Tabel 1. Hasil Analisis Sampel Tanah Awal.

\begin{tabular}{lcc}
\hline Sifat Tanah & Nilai Pengukuran & Kriteria \\
\hline N-total (\%) & 0,11 & Rendah \\
P-tersedia (ppm) & 1,79 & Sangat Rendah \\
P-total $(\mathrm{ppm})$ & 84,84 & Sangat Tinggi \\
C-organik $(\%)$ & 1,46 & Rendah \\
pH $\left(\mathrm{H}_{2} \mathrm{O}\right)$ & 6,56 & Netral \\
\hline
\end{tabular}

Keterangan: Kriteria tanah bersumber dari Balai Penelitian Tanah (2009).

sebanyak dua kali, setengah dosis pada awal masa tanam dan setengah berikutnya saat tanaman mulai memasuki fase generatif. Pupuk KCl diberikan dengan dosis $200 \mathrm{~kg} \mathrm{ha}^{-1}\left(1 \mathrm{~g}\right.$ tanaman $\left.^{-1}\right)$. Pupuk SP-36 diberikan dalam jumlah dosis $150 \mathrm{~kg} \mathrm{ha}^{-1}(0,75 \mathrm{~g}$ tanaman $^{-1}$ ) sedangkan pupuk BFA diberikan dalam jumlah dosis $192,85 \mathrm{~kg} \mathrm{ha}^{-1}\left(0,95 \mathrm{~g}\right.$ tanaman $\left.^{-1}\right)$ sesuai dengan perlakuan masing-masing. Aplikasi pupuk dilakukan dengan mencampurkan pupuk pada tanah yang telah diayak halus dengan cara dilarik melingkar berjarak $5 \mathrm{~cm}$ dari lubang tanam lalu ditutup tipis dengan tanah.

Pembuatan konsorsium BPF dilakukan dengan memanen setiap tabung isolat BPF dengan menggunakan jarum ose kemudian dibuat suspensi BPF dengan dicampurkan ke dalam air steril lalu dihomegenkan dengan menggunakan vorteks mixer. Konsorsium BPF yang telah dibuat diaplikasikan untuk setiap jenis perlakuan yang ada dengan takaran dosis sebanyak $350 \mathrm{ml}$ per tanaman.

Penyiraman dilakukan setiap hari dengan volume air 1 liter per polybag pada pagi dan sore hari. Pemasangan ajir (turus) dilakukan saat tanaman berumur 5 HST menggunakan bambu yang dibelah dengan tinggi $200 \mathrm{~cm}$. Pengendalian gulma dilakukan dari awal penanaman dengan cara dicabut secara langsung. Perawatan rambatan tanaman dilakukan dengan mengikat batang tanaman menggunakan tali rapia pada ajir setiap jarak tumbuh $30 \mathrm{~cm}$. Panen dilakukan dengan selang waktu $2-3$ hari sekali setelah tanaman umur 40 -70 HST. Buah mentimun siap dipanen pada umur 10 - 15 hari setelah bunga betina mengalami anthesis.

\section{HASIL DAN PEMBAHASAN}

Perlakuan pupuk SP-36 $150 \mathrm{~kg} \mathrm{ha}^{-1}$ dan BFA $192,85 \mathrm{~kg} \mathrm{ha}^{-1}$ dapat meningkatkan produksi masingmasing 78\% dan 40\% dibandingkan dengan kontrol (Tabel 2). Hal ini diduga adanya ketersediaan unsur fosfor bagi tanaman untuk melakukan proses pertumbuhan secara maksimal. Dalam penelitian Adam et al. (2013) melaporkan, perlakuan pupuk fosfor 200 $\mathrm{kg} \mathrm{ha}^{-1}$ berpengaruh nyata dalam meningkatkan berat buahmentimun.

Selain itu, hasil bobot buah dengan perlakuan pupuk SP-36 $150 \mathrm{~kg} \mathrm{ha}^{-1}\left(\mathrm{P}_{1}\right)$ dan BFA 192,85 $\mathrm{kg} \mathrm{ha}^{-}$ ${ }^{1}\left(\mathrm{P}_{2}\right)$ baru mencapai $27,18 \%$ dan $21,40 \%$ dari potensial hasil yang dapat dihasilkan tanaman mentimun varietas F1 Mercy $\left(50\right.$ ton $\left.\mathrm{ha}^{-1}\right)$. Hal ini diduga karena curah hujan yang rendah selama periode tanam menyebabkan tingginya penguapan air dari media tanam. Selain itu, penggunaan polybag yang tidak 
Tabel 2. Pengaruh Jenis Sumber Pupuk P terhadap Produksi Tanaman Mentimun (Cucumis sativus L.).

\begin{tabular}{lc}
\hline Perlakuan & Produksi (ton ha $\left.{ }^{-1}\right)$ \\
\hline Tanpa Pupuk P $\left(\mathrm{P}_{0}\right)$ & $7,63 \mathrm{~b}$ \\
SP-36 $\left(\mathrm{P}_{1}\right)$ & $13,59 \mathrm{a}$ \\
BFA $\left(\mathrm{P}_{2}\right)$ & $10,70 \mathrm{ab}$ \\
\hline
\end{tabular}

Keterangan : Nilai rata-rata yang diikuti huruf yang sama tidak berbeda nyata berdasarkan uji DMRT pada taraf 5\%.

Tabel 3. Pengaruh Jenis BPF terhadap kandungan klorofil dan dan usia berbunga pada Tanaman Mentimun (Cucumis sativus L.).

\begin{tabular}{lcc}
\hline Perlakuan & Kandungan Klorofil & Usia Berbunga (HST) \\
\hline Tanpa BPF $\left(\mathrm{M}_{0}\right)$ & $56,50 \mathrm{ab}$ & $29,44 \mathrm{ab}$ \\
BPF TKKS $\left(\mathrm{M}_{1}\right)$ & $60,59 \mathrm{a}$ & $32,22 \mathrm{a}$ \\
BPF RN $\left(\mathrm{M}_{2}\right)$ & $47,91 \mathrm{~b}$ & $29,67 \mathrm{ab}$ \\
Kombinasi BPF TKKS+RN $\left(\mathrm{M}_{3}\right)$ & $61,74 \mathrm{a}$ & $28,56 \mathrm{~b}$ \\
\hline
\end{tabular}

Keterangan : Nilai rata-rata yang diikuti huruf yang sama tidak berbeda nyata berdasarkan uji DMRT pada taraf $5 \%$. HST $=$ Hari Setelah Tanam.

diberikan alas di bawah permukaannya menyebabkan air yang keluar saat penyiraman tidak tertampung sehingga tidak dapat diserap kembali oleh akar tanaman. Faktor kekurangan air tersebut diduga menjadi faktor penghambat utama sehingga tanaman tidak mampu menghasilkan jumlah buah (Tabel 4) dari potensial jumlah buah yang dapat dihasilkan tanaman mentimun varietas F1 Mercy (8-9 buah $\tan ^{-1}$ ).

Hasil penelitian ini menunjukkan bahwa jenis BPF tidak berpengaruh dalam meningkatkan pertumbuhan dan produksi tanaman mentimun. Hasil uji DMRT 5\% menunjukkan adanya pengaruh jenis BPF pada variabel kandungan klorofil dan usia berbunga (Tabel 3), namun hasil yang diperoleh menunjukkan hasil yang tidak lebih baik dibandingkan perlakuan tanpa BPF $\left(\mathrm{M}_{0}\right)$. Hal ini diduga karena bakteri pelarut fosfat (BPF) yang diberikan belum dapat berkembang secara baik dikarenakan minimnya bahan organik (Tabel 1). Bakteri pelarut fosfat memerlukan energi untuk aktivitas metabolismenya, salah satu sumbernya adalah bahan organik. Menurut Ginting (2006), keberadaan mikroorganisme pelarut fosfat berkaitan dengan banyaknya jumlah bahan organik yang secara langsung mempengaruhi populasi dan aktivitas dari BPF. Dalam penelitian lainnya, Alori et al. (2017) menyatakan bahwa tanah yang kaya dengan bahan organik akan mendukung pertumbuhan mikroba sehingga akan lebih banyak melarutkan fosfat.

Pupuk SP-36 $150 \mathrm{~kg} \mathrm{ha}^{-1}$ meningkatkan produksi tanaman yang diikuti oleh peningkatan variabel jumlah cabang, bobot kering akar, bobot kering brangkasan, usia berbunga, jumlah bunga betina, dan jumlah buah (Tabel 4). Hal ini diduga karena tersedianya unsur fosfor bagi tanaman sehingga dapat dimanfaatkan oleh tanaman untuk pertumbuhan. Jenis pupuk SP-36 memiliki kelebihan berupa kandungan $\mathrm{P}$ yang cukup tinggi dan lebih mudah tersedia untuk diserap akar tanaman. Hal ini juga sesuai dengan penelitian Badrudin et al. (2008), bahwa perlakuan pupuk fosfat nyata meningkatkan variabel pertumbuhan tanaman termasuk bobot basah dan bobot kering tanaman mentimun. Selain itu, menurut Bachtiar et al. 
(2013), pemupukan SP-36 nyata berpengaruh dalam meningkatkan berat kering tanaman padi.

Menurut Karnomo (1989), unsur fosfat dengan unsur nitrogen dapat mendorong pertumbuhan akar dengan merangsang pembentukan bulu-bulu akar. Hal ini menyebabkan unsur hara dan air dapat terserap secara maksimal. Proses penyerapan unsur hara yang meningkat menyebabkan proses pertumbuhan berlangsung secara maksimal, seperti pertumbuhan jumlah daun pada tanaman. Jumlah daun yang lebih banyak akan memungkinkan tanaman untuk menghasilkan fotosintat yang lebih banyak. Hasil fotosintat akan ditranslokasikan ke seluruh jaringan tanaman dan sisanya akan ditimbun. Semakin banyak fotosintat yang ditimbun pada jaringan tanaman, maka semakin meningkatkan bobot kering pada brangkasan tanaman mentimun. Selain itu, unsur hara yang cukup dapatmenunjang pertumbuhan organ tanaman, termasuk jumlah cabang tanaman. Menurut Sasmita dan Pranowo (2011), pemberian dosis pupuk $P$ terbaik nyata dapat meningkatkan jumlah cabang dan diameter tanaman.

Perlakuan pupuk SP-36 $150 \mathrm{~kg} \mathrm{ha} \mathrm{h}^{-1}$ memberikan pengaruh nyata dan lebih cepat terhadap usia berbunga tanaman (Tabel 4). Hal ini diduga karena ketersediaan P pada SP-36 yang lebih mudah tersedia sehingga tanaman mampu mencapai stadia matang untuk dapat berbunga lebih cepat. Pembungaan tanaman dipengaruhi oleh beberapa faktor, yaitu : (1) kemampuan genotip tanaman, (2) kemampuan tanaman dalam mencapai stadia matang untuk berbunga, (3) adanya zat pengatur tumbuh yang mengatur pembungaan. Hasil penelitian dari Adam et al. (2013) melaporkan bahwa perlakuan pupuk fosfor dengan SP36 (150 kg ha' ${ }^{-1}$ dan $\left.200 \mathrm{~kg} \mathrm{ha}^{-1}\right)$ memberikan ratarata umurberbunga lebih cepat pada tanaman mentimun. Selain itu, Batubara (2017) melaporkan bahwa pemberian pupuk SP-36 menghasilkan umur berbunga tercepat yaitu 48,22 HST pada tanaman jagung di Kabupaten Asahan Sumatera Utara.

Selanjutnya, perlakuan pupuk SP-36 $150 \mathrm{~kg}$ $\mathrm{ha}^{-1}$ memberikan pengaruh nyata terhadap jumlah bunga betina dan jumlah buah per tanaman (Tabel 4). Peningkatan jumlah bunga betina diduga karena jumlah daun yang lebih banyak pada tanaman dengan perlakuan pupuk SP-36 $150 \mathrm{~kg} \mathrm{ha}^{-1}$. Bunga pada tanaman mentimun muncul pada ketiak daun, sehingga jumlah bunga yang muncul pada tanaman mentimun dipengaruhi oleh jumlah daun dan ruas pada tanaman mentimun itu sendiri (Zamzami, et al., 2015). Pada penelitian ini diketahui bahwa perlakuan pupuk SP-36

Tabel 4. Pengaruh Jenis Pupuk Fosfat terhadap Jumlah Cabang, Bobot Kering Akar, Bobot Kering Brangkasan, Usia Berbunga, Jumlah Bunga Betina, dan Jumlah Buah.

\begin{tabular}{lcccccc}
\hline Perlakuan & $\begin{array}{c}\text { JC } \\
(\text { tangkai) }\end{array}$ & $\begin{array}{c}\text { BKA } \\
\left(\mathrm{g} \mathrm{tan}^{-1}\right)\end{array}$ & $\begin{array}{c}\text { BKB } \\
\left(\mathrm{g} \mathrm{tan}^{-1}\right)\end{array}$ & $\begin{array}{c}\text { UB } \\
(\mathrm{HST})\end{array}$ & $\begin{array}{c}\text { JBB } \\
(\text { buah })\end{array}$ & $\begin{array}{c}\text { JB } \\
\text { (buah) }\end{array}$ \\
\hline Tanpa Pupuk P $\left(\mathrm{P}_{0}\right)$ & $0,92 \mathrm{~b}$ & $2,04 \mathrm{~b}$ & $14,94 \mathrm{~b}$ & $32,58 \mathrm{a}$ & $3,00 \mathrm{~b}$ & $1,42 \mathrm{~b}$ \\
SP-36 $\left(\mathrm{P}_{1}\right)$ & $1,75 \mathrm{a}$ & $3,25 \mathrm{a}$ & $26,75 \mathrm{a}$ & $27,50 \mathrm{c}$ & $5,17 \mathrm{a}$ & $2,75 \mathrm{a}$ \\
BFA $\left(\mathrm{P}_{2}\right)$ & $1,08 \mathrm{ab}$ & $2,90 \mathrm{a}$ & $19,40 \mathrm{~b}$ & $29,83 \mathrm{~b}$ & $3,17 \mathrm{~b}$ & $1,75 \mathrm{~b}$ \\
\hline
\end{tabular}

Keterangan : JC = Jumlah Cabang; BKA = Bobot Kering Akar; BKB = Bobot Kering Brangkasan; UB = Usia Berbunga; $\mathrm{JBB}=$ Jumlah Bunga Betina; JB = Jumlah Buah; Nilai rata-rata yang diikuti huruf yang sama tidak berbeda nyata berdasarkan uji DMRT pada taraf $5 \%$. 
$150 \mathrm{~kg} \mathrm{ha}^{-1}$ memberikan jumlah daun lebih banyak dibandingkan perlakuan lainnya. Jumlah daun yang lebih banyak inilah yang menyebabkan jumlah bunga betina pada perlakuan SP-36 $150 \mathrm{~kg} \mathrm{ha}^{-1}$ juga lebih banyak daripada perlakuan lainnya. Jumlah buah pada tanaman mentimun ditentukan oleh jumlah bunga yang muncul, sehingga semakin banyak bunga yang muncul, maka semakin banyak pula buah yang terbentuk.

Pengaruh interaksi antara perlakuan pupuk SP$36150 \mathrm{~kg} \mathrm{ha}^{-1}$ dengan berbagai jenis BPF memberikan pengaruh nyata dalam meningkatkan pertumbuhan panjang tanaman dibandingkan dengan tanpa BPF $\left(\mathrm{M}_{0}\right)$ (Tabel 5). Perlakuan pupuk SP-36 $150 \mathrm{~kg} \mathrm{ha}^{-1}$ dengan jenis BPF dari MOL TKKS berpengaruh dalam meningkatkan panjang tanaman. Hal ini dapat disebabkan karena kandungan pupuk SP-36 yang cukup tinggi dan adanya BPF yang diduga mampu melarutkan fosfor yang terjerap menjadi bentuk fosfor yang tersedia bagi tanaman. Menurut Rachman (2018), menyatakan bahwa isolat bakteri pelarut fosfat dengan pupuk memberikan pengaruh nyata terhadap tinggi tanaman, berat basah dan berat kering pada tanaman tomat.
Hasil lain menunjukkan bahwa perlakuan BPF dari MOL asal rimpang nanas dengan tanpa pupuk $\mathrm{P}$ memberikan hasil yang tidak berbeda dengan perlakuan dengan penambahan pupuk P. Hal ini diduga karena adanya proses pelarutan fosfat dari tanah awal yangmemilikipotensi kandungan Pcukup tinggi(Tabel 1).

Pengaruh interaksi antara jenis BPF dengan jenis pupuk $P$ terhadap jumlah daun tanaman pada pengamatan 42 HST disajikan pada Tabel 6. Pada perlakuan pupuk SP-36 $150 \mathrm{~kg} \mathrm{ha}^{-1}$ dengan BPF terbaik dari MOL TKKS memberikan pengaruh nyata dalam meningkatkan jumlah daun tanaman. Hal ini diduga karena kandungan pupuk SP-36 yang cukup tinggi dan adanya BPF yang mampu melarutkan fosfor yang terjerap menjadi bentuk fosfor yang tersedia bagi tanaman. Menurut Andayani (2018), bahwa isolat bakteri dari suspensi ekstrak TKKS yang bersifat hipovirulen dapat dimanfaatkan sebagai Plant Growth Promoting Bacteria (PGPB) untuk membantu pertumbuhan tanaman.

Bakteri Pelarut Fosfat(BPF) tidak memberikan pengaruh dalam meningkatkan pertumbuhan dan produksi tanaman mentimun (Cucumis sativus L.). Hal

Tabel 5. Pengaruh Aplikasi Jenis Bakteri Pelarut Fosfat (BPF) dan Jenis Sumber Pupuk P terhadap Panjang Tanaman (cm) pada Pengamatan 42 HST.

\begin{tabular}{ccccc}
\hline \multirow{2}{*}{ Jenis Pupuk P } & \multicolumn{4}{c}{ Jenis BPF } \\
\cline { 2 - 5 } & Tanpa BPF & $\begin{array}{c}\text { BPF TKKS } \\
\left(\mathrm{M}_{0}\right)\end{array}$ & $\begin{array}{c}\text { BPF RN } \\
\left(\mathrm{M}_{2}\right)\end{array}$ & $\begin{array}{c}\text { Kombinasi BPF TKKS + } \\
\text { RN }\left(\mathrm{M}_{3}\right)\end{array}$ \\
\hline Tanpa Pupuk P & $84,67 \mathrm{~b}$ & $65,67 \mathrm{~b}$ & $108,00 \mathrm{a}$ & $100,00 \mathrm{~b}$ \\
$\left(\mathrm{P}_{0}\right)$ & $\mathrm{AB}$ & $\mathrm{B}$ & $\mathrm{A}$ & $\mathrm{A}$ \\
SP-36 & $110,33 \mathrm{a}$ & $143,00 \mathrm{a}$ & $119,33 \mathrm{a}$ & $130,33 \mathrm{a}$ \\
$\left(\mathrm{P}_{1}\right)$ & $\mathrm{B}$ & $\mathrm{A}$ & $\mathrm{AB}$ & $\mathrm{AB}$ \\
BFA & $88,00 \mathrm{~b}$ & $87,33 \mathrm{~b}$ & $93,33 \mathrm{a}$ & $107,00 \mathrm{~b}$ \\
$\left(\mathrm{P}_{2}\right)$ & $\mathrm{A}$ & $\mathrm{A}$ & $\mathrm{A}$ & $\mathrm{A}$ \\
\hline
\end{tabular}

Keterangan : Nilai rata-rata yang diikuti huruf yang sama tidak berbeda nyata berdasarkan uji DMRT pada taraf $5 \%$, huruf kecil dibaca vertikal dan huruf kapital dibaca horizontal. TKKS = Tandan Kosong Kelapa Sawit; RN = Rimpang Nanas. 
Tabel 6. Pengaruh Aplikasi Jenis Bakteri Pelarut Fosfat (BPF) dan Jenis Sumber Pupuk P terhadap Jumlah Daun (helai) pada Pengamatan $42 \mathrm{HST}$.

\begin{tabular}{ccccc}
\hline \multirow{2}{*}{ Jenis Pupuk P } & \multicolumn{4}{c}{ Jenis BPF } \\
\cline { 2 - 5 } & $\begin{array}{c}\text { Tanpa BPF } \\
\left(\mathrm{M}_{0}\right)\end{array}$ & $\begin{array}{c}\text { BPF TKKS } \\
\left(\mathrm{M}_{1}\right)\end{array}$ & $\begin{array}{c}\text { BPF RN } \\
\left(\mathrm{M}_{2}\right)\end{array}$ & $\begin{array}{c}\text { Kombinasi BPF TKKS + } \\
\text { RN }\left(\mathrm{M}_{3}\right)\end{array}$ \\
\hline Tanpa Pupuk P & $17,67 \mathrm{~b}$ & $10,33 \mathrm{c}$ & $19,67 \mathrm{a}$ & $19,33 \mathrm{~b}$ \\
$\left(\mathrm{P}_{0}\right)$ & $\mathrm{A}$ & $\mathrm{B}$ & $\mathrm{A}$ & $\mathrm{A}$ \\
SP-36 & $24,67 \mathrm{a}$ & $31,00 \mathrm{a}$ & $23,33 \mathrm{a}$ & $26,67 \mathrm{a}$ \\
$\left(\mathrm{P}_{1}\right)$ & $\mathrm{B}$ & $\mathrm{A}$ & $\mathrm{B}$ & $\mathrm{B}$ \\
BFA & $17,67 \mathrm{~b}$ & $18,67 \mathrm{~b}$ & $20,33 \mathrm{a}$ & $20,33 \mathrm{~b}$ \\
$\left(\mathrm{P}_{2}\right)$ & $\mathrm{A}$ & $\mathrm{A}$ & $\mathrm{A}$ & $\mathrm{A}$ \\
\hline
\end{tabular}

Keterangan : Nilai rata-rata yang diikuti huruf yang sama tidak berbeda nyata berdasarkan uji DMRT pada taraf 5\%, huruf kecil dibaca vertikal dan huruf kapital dibaca horizontal. TKKS = Tandan Kosong Kelapa Sawit; RN = Rimpang Nanas.

ini diduga karena bakteri pelarut fosfat (BPF) yang diberikan belum dapat berkembang secara baik dikarenakan minimnya kandungan karbon (C) di dalam media tanam sehingga perlu penambahan bahan organik steril untuk meningkatkan pengaruh BPF. Pupuk SP36 meningkatkan produksi dan jumlah buah mentimun sebesar 78\% dan 94\% dibandingkan dengan tanpa pupuk P. Hal ini diduga karena pupuk SP-36 dapat menyediakan P lebih banyak sehingga tanaman dapat tumbuh dan berproduksi lebih baik. Penambahan BPF dari MOL TKKS dengan pupuk SP-36 bisa direkomendasikan karenakan interaksi keduanya mampu meningkatkan pertumbuhan tanaman mentimun berdasarkan pengamatan panjang tanaman dan jumlah daun.

\section{KESIMPULAN}

Berdasarkan hasil penelitian menunjukkan bahwa (1) perlakuan bakteri pelarut fosfat (BPF) tidak memberikan pengaruh terhadap pertumbuhan dan produksi tanaman mentimun (Cucumis sativus L.), (2) pupuk SP-36 menghasilkan produksi dan jumlah buah mentimun lebih baik masing-masing sebesar $78 \%$ dan 94\% dibandingkan dengan tanpa pupuk $\mathrm{P}$ yang didukung oleh peningkatan variabel bobot kering akar, bobot kering brangkasan, usia berbunga, dan jumlah bunga betina, (3) BPF dari MOL TKKS dengan pupuk SP-36 memberikan pengaruh lebih baik terhadap pertumbuhan tanaman mentimun berdasarkan pengamatan panjang tanaman dan jumlah daun.

\section{UCAPAN TERIMA KASIH}

Penelitian ini merupakan bagian dari Penelitian Hibah Profesor tahun anggaran 2019 atas nama Prof. Dr. Ir. Dermiyati, M.Agr.Sc., Dr. Suskandini Ratih, dan Dr. Mareli Telaumbanua yang didanai oleh DIPABLU Unila. Penulis mengucapkan terima kasih kepada LPPM Unila dan Fakultas Pertanian Unila atas terlaksananya kegiatan penelitian ini.

\section{DAFTAR PUSTAKA}

Adam, S. Y., Bahua, M.I., dan Jamin, F.S. 2013. Pengaruh Fosfor pada Pertumbuhan dan Produksi Tanaman Mentimun. Gorontalo. $24 \mathrm{hlm}$.

Alori, E.T., Glik, B.R., and Babalola, O.O. 2017. Microbial Phosphorus Solubilization And Its 
Potential for Use in Sustainable Agriculture. Frontiers in Microbiology. 8: $1-8$.

Andayani, A.P. 2019. Populasi dan Karakterisasi Bakteri dalam Suspensi Ekstrak Tandan Kosong Kelapa Sawit (Elaeis guineensis Jacq.) (Skripsi). Universitas Lampung. Bandar Lampung. $46 \mathrm{hlm}$.

Bachtiar, T., Waluyo, S.H., Syaukat, S.H. 2013. Pengaruh Pupuk Kandang dan SP-36 terhadap Pertumbuhan Padi Sawah. Jurnal Ilmiah Aplikasi Isotop dan Radiasi A Scientific Journal for The Applications of Isotopes and Radiation. 9(2): 151 - 159.

Badrudin, U., Jazilah, S., dan Setiawan, A. 2008. Upaya Peningkatan Produksi Mentimun (Cucumis sativus L.) Melalui Waktu Pemangkasan Pucuk dan Pemberian Pupuk Posfat. Universitas Pekalongan. hal. $18-28$.

Batubara, L.R. 2017. Pengaruh Aplikasi Pupuk SP36 terhadap Pertumbuhan dan Produksi Tanaman Jagung Manis (Zea mays saccharata Sturt). BERNAS Agricultural Research Journal.. 14: 1 - 9.

BPS. 2018. Statistik Tanaman Sayuran dan Buah-buahan Semusim Indonesia. BPS-Statistics Indonesia. Jakarta. https://www.bps.go.id/. $111 \mathrm{hlm}$.

Dermiyati, Suharjo, R., Telaumbanuwa, M., Ilmiasari, Y., Yosita, R., Annisa, R.M., Sari, A.W., Andayani, A.P., and Yulianti, D.M. 2019. Population of Phosphate Solubilizing Bacteria in Liquid Organic Biofertilizer Created From Oil Palm Bunches and Pineapple Rhizome. Biodiversitas. 20(11): 3315 - 3321.
Ginting, R.C., Saraswati, R., dan Husen, E. 2006. Pupuk Organik dan Pupuk Hayati. Balai Penelitian Tanah. Bogor. $18 \mathrm{hlm}$.

Karnomo. 1989. Pengantar Produksi Tanaman Agronomi (Diktat). Universitas Jenderal Soedirman. Purwokerto. $34 \mathrm{hlm}$.

Kaya, E. 2012. Pengaruh Pupuk Kalium dan Fosfat terhadap Ketersediaan dan Serapan Fosfat Tanaman Kacang Tanah (Arachis hypogaea L.) pada Tanah Bruniezem. Agrologia. 1(2): $113-118$.

Khan, M. S., Zaidi, A., and Wani, P.A. 2006. Role of Phosphate-solubilizing Microorganisms in Sustainable Agriculture - A review. Agro. Sustain. Dev. 29 - 43 pp.

Rachman, F. N. 2018. Pengaruh Aplikasi Bakteri Pelarut Fosfat dan Pupuk Kandang Sebagai Biofertilizer Terhadap Pertumbuhan dan Hasil Produksi Tanaman Tomat (Skripsi). UIN Maulana Malik Ibrahim. Malang. $110 \mathrm{hlm}$.

Sasmita, K.D. dan Pranowo, D. 2011. Pengaruh Pupuk Majemuk NPK dan Fosfat Terhadap Pertumbuhan dan Produksi Jarak Pagar IP3P. Buletin RISTRI. 2(3): 311 - 318 .

Subba-Rao, N. S. 1982. Phosphate solubilization by Soil Microorganisms. IBH Publishing Co. New Delhi. Pp 295 - 303.

Zamzami, K., Nawawi, M., dan Aini, N. 2015. Pengaruh Jumlah Tanaman Per Polybag dan Pemangkasan terhadap Pertumbuhan dan Hasil Tanaman Mentimun Kyuri (Cucumis sativus L.). Jurnal Produksi Tanaman. 3(2): 113 - 119. 